\title{
Characteristics of Mahogany Stomata (Swietenia macrophylla K.) in Polluted Environments
}

\author{
Des $\mathrm{M}^{1 *}$ Vauzia $^{1}$ Yensi Sri Gusti ${ }^{1}$
}

\author{
${ }^{1}$ Dept. of Biology, Faculty of Mathematics and Science (FMIPA), Universitas Negeri Padang, Padang, Indonesia \\ *Corresponding author. Email: des.unp@gmail.com
}

\begin{abstract}
One of a plant that is usually used as a green roadside plant in the urban area is mahogany (Swietenia macrophylla K.). The influence of environmental pollution in plants can be seen from stomata in the leaves. This study was aimed to determine the characteristic of the mahogany leaf stomata in a polluted environment. The observed characteristics were a type of stomata, density and distribution stomata. The research was conducted in March to July 2019 in the Botanical Laboratory, Faculty of Mathematics and Science of Natural Sciences, Universitas Negeri Padang. Samples were collected on Prof. Dr. Hamka street and controls were collected at Bung Hatta Forest Parks. The method of stomata observation was a replica method. The type of stomata found was anomocytic. The difference in stomata density in both locations was significant. The stomata density on Jl. Prof. Dr. Hamka was higher than that of Bung Hatta Forest Parks. Stomata of mahogany were found on the lower part of the leaf or also called hypostomatic distributed.
\end{abstract}

Keywords: Mahogany (Swietenia macrophylla K.), Stomata

\section{INTRODUCTION}

In the life of living, things in this world air is an important factor. In line with the development of the physical development of cities and industrial centers, as well as the development of transportation in this modern era, the air quality has also experienced changes caused by air pollution. Air pollution is changing one air composition of a normal state, which is caused by the entry of contaminants in the form of gases and tiny particles into the air in a certain amount for a period long enough. As a result of this contamination can interfere with human, animal, and plant in [1]. Air pollution occurs when the air contains one or more pollutants obtained from chemical processes such as gases $\mathrm{CO}, \mathrm{O} 3, \mathrm{CO} 2, \mathrm{SO}, \mathrm{H} 2 \mathrm{O}, \mathrm{SO} 2$, $\mathrm{NOX}, \mathrm{C} 2 \mathrm{H} 4$, and $\mathrm{Pb}$ as well as the presence of particulate dust, all of which exceed the threshold [2].

Padang city is one of the cities that has an increasing number of vehicles annually. An increasing number of people each year cause an increased number of vehicles motorized. The Central Statistics Agency of Padang said residents of Padang in 2016 amounted to 909.000 lives and increasing to 927.168 inhabitants in 2017. To carry out its activities people in Padang city prefer to use private vehicles than use public transport [3]. This lead to the increase of vehicles on the street. The presence of the shopping center and the center education from pre-school to college on Prof. Dr. Hamka street is one of the causes of the density of vehicles passing by every day. Due to the high mobility of these vehicles, this led to the mobility of trips to the road sections becomes high so that increase the emission of $\mathrm{CO}$ could degrade air quality. The results of Wijaya's research [4] show the air pollution index on Prof.
Dr. Hamka street amounted to 56.67 which included the category of unhealthy air.

Air pollution needs to be monitored and controlled. Meanwhile, Kovack [5] states, that one of the ways of monitoring air pollution is to use plants as bio-indicators. Parts of plants that function as absorbents of pollutants are the canopy, especially the leaves. Thus the leaves are plant organs as bio-indicators that are most sensitive to the environment. To determine the level of air pollution can be seen from the damage macroscopic or microscopic on the plant organs. A similar thing also expressed by Karliansyah [6], the plants are sensitive to air pollutants will reflect the changes in morphology, anatomy, physiology, and biochemistry. To determine the effect of air pollution on the leaves can be seen from both macroscopic damages such as chlorosis, necrosis, or microscopically like cell structure or changes in physiology and chemistry of plants.

Plants can be used to decrease pollutants in the environment in two ways, that are absorbed (absorb) or sequestered (adsorb). Absorbed means the entry of pollutants to the structure of the leaf through the stomata, while sequestered means pollutant only stick on the surface of leaves and allow the release and becomes pollutants again [7]. The sensitivity of plants associated with its ability to absorb and accumulate contaminants. Contaminants will enter the leaf through the stomata which are also influenced by the surrounding air condition. This is because the stomata serve as the gateway of gas and water vapor exchange between plants and the surrounding environment [8]. [7] The ability of plants to absorb the pollutants contained in the air also depends on the morphology of the plants. The type of plants which has on both sides of the leaf stomata is relatively more 
potential to absorb gases in the vicinity including the pollutants contained in the air.

To reduce pollution, greening activities are carried out to realize the city environment into an environmentally friendly region with a beautiful, harmonious, and cool atmosphere that can be done in many ways. As a form of urban greening, including urban forest development, green belt, greening with potted plants. Greening the city into a form of the biological environment with a variety of functions in environmental governance [9]. Dahlan [10] suggested greening the city serves as the lungs of the city because the plants produce oxygen gas that is required of all living things, to absorb toxic gases or particles to reduce air pollution and as a noise reducer of transportation. Antari and Sundra [11] also found greening can be done by planting crops which functions to increase the aesthetics also serves to reduce air pollution. Protective plants that can be used for reforestation are ketapang, glodokan, trembesi, mahogany and others.

The green plants that are often found along the streets of the city of Padang are mahogany. The exposure of these green plants to pollutants will certainly affect the stomata of the leaves. Based on this it is necessary to know about "Characteristics of Mahogany Stomata (Swietenia macrophylla K.) in polluted environments."

\section{MATERIALS AND METHODS}

\subsection{Equipment and Material}

In this study, the tools used were scissors, plastic bags, tissue, transparent insulation, paper label, object and cover glass, Zeiss Primo Starlight microscopy and digital microscopes. The material used in this study is a transparent nail polish and leaf mahogany (Swietenia macrophylla K.)

\subsection{Sampling}

Leaf samples were taken on Prof. Dr. Hamka street and control plants at Bung Hatta Forest Parks. For a representative sample of leaves, leaf samples were taken as many as ten sheets at each location. Leaf samples were taken at 09: 00-12: $00 \mathrm{pm}$. Samples have been taken are labeled by capture location, and then inserted into a plastic bag so plants do not wither. The research had done in the laboratory of Botany Department of Biology, Faculty of Mathematics and Natural Sciences, State University of Padang.

Making Stomata Preparation

The method used is a replica method by smearing colored nail polish clear in the lower and upper surfaces of leaves in the middle and let it dry. Then on the coated nail polish plastered with insulation and withdrawn slowly and then placed on a glass object. Then observed under a light microscope at a magnification Zeiss Primo Star 10x40 and the result was photographed with a digital microscope. Parameters measured were the type of stomata, stomatal density, and distribution of stomata.

Stomata Density Calculation

To determine the density of stomata, known in advance the broad field of vision, a wide field of view in the study of $168 \mu \mathrm{m} 2$ which was then inserted into the formula [12] Density $=$ Number of Stomata / wide Field of View.

Determination of Stomata Distribution

Stomata distribution is classified according to whether it is amphistomatic (stomata are on both leaf surfaces), epistomatic (stomata is only on the upper surface of the leaf) and hypostomatic (stomata is only on the underside of the leaf) [13].

\subsection{Data analysis}

The data were analyzed by the T-test with a significance level of $5 \%$.

\section{RESULT AND DISCUSSION}

The type of Stomata of mahogany is animosity (Figure 2), meaning that cover cells surrounded by several different sizes of cells and shapes of the other epidermal cells. The results of a comparative analysis of the T-test density of stomata leaf mahogany (Swietenia macrophylla K.) at the location of Bung Hatta Forest Parks and Prof.Dr. Hamka street can be seen in Table 1 below:

Table 1. Data on average density of stomata leaf mahogany (Swietenia macrophylla K.)

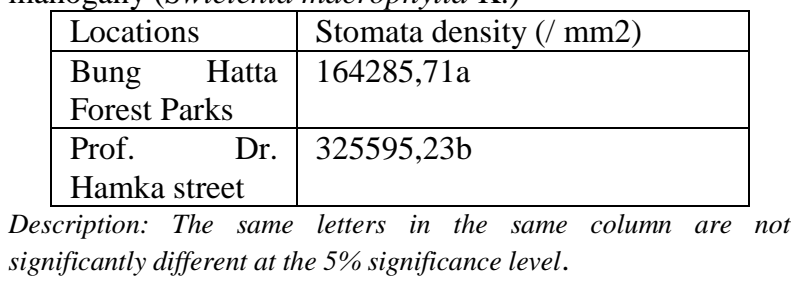

The results showed that the density of stomata mahogany plants on Prof. Dr. Hamka street is higher than the Bung Hatta Forest Park. That means stomata in polluted areas are higher than in areas that are not polluted. This is consistent with the result of research of [14] also showed that the density and damage to stomata of mango leaves (Mangifera indica) that grow on the side of the road which is mostly passed by motorized vehicles are higher than in the Nature Reserve. The same thing was stated by [15] Mallotus leucodermis stomata density of seed regeneration and shoot regeneration at burnt locations is higher than unburnt locations

The high number of stomata in polluted areas compared to non-polluted areas is a form of physiological adaptation due to air pollution. Pollutants attached to the stomata will accumulate and if in large numbers can damage stomata cells. Damaged stomata cells will stimulate the production 
of stomata in greater numbers so that the process of photosynthesis runs normally as a form of adaptation [14]. Prawiranata and Tjondronegoro [16] stated that besides stomata frequency pollutants are also influenced by environmental conditions. The leaves of plants that grow in a dry environment and under high-intensity light have many stomata. Thus, stomata density is influenced not only by pollutants but also by light intensity. Light intensity is influenced by vegetation cover factor. The intensity of the light at the sampling location is different, the intensity of the light in the Bung Hatta Forest Park is lower because many large trees cover the vegetation while on the edge of Prof. Dr. Hamka street high light intensity due to the lack of protective trees planted by the roadside. The observation of the longitudinal cross-section of mahogany leaves on the upper surface (adaxial) and lower surface (abaxial) can be seen in Figure 1 and parts of the stomata can be seen in Figure 2. Stomata on Mahogany leaves are only found on the underside of the leaf.

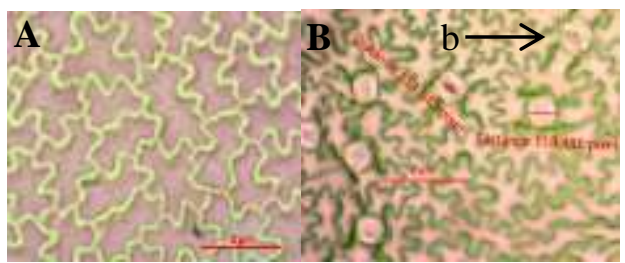

Figure 1.Longitudinal cross section of mahogany (A) Adaxial (B) Abaxial (b) Stomata

\section{CONCLUSION}

From the results of the study, it can be concluded that the stomata density of mahogany leaves (Swietenia macrophylla K.) on the edge of Prof. Dr. Hamka street, which is passed by many motorized vehicles, is higher than in the Bung Hatta Forest Park. Ketapang leaf stomate distribution is only found on the lower surface or hypostomatic type.

\section{REFERENCES}

[1] Ismiyati, D. Marlita., dan D. Saidah. 2014. Pencemaran Udara Akibat Emisi Gas Buang Kendaraan Bermotor. Jurnal Manajemen Transportasi \& Logistik (JMTransLog). 1(3) November 2014 ISSN: 2355-4721.

[2] Lutfi, A. 2009. Pencemaran Udara dan Penanggulangannya. Malang: UMMU.

[3] Desiyanti, A. 2018. Statistik Daerah Kota Padang 2018. Padang: BPS Kota Padang.

[4] Wijaya, P I. 2018. Analisis Pencemaran Udara Akibat Kepadatan Jalan Lalu Lintas di Kota Padang (Studi Kasus: Karbon Monoksida di Jalan Prof Dr Hamka,

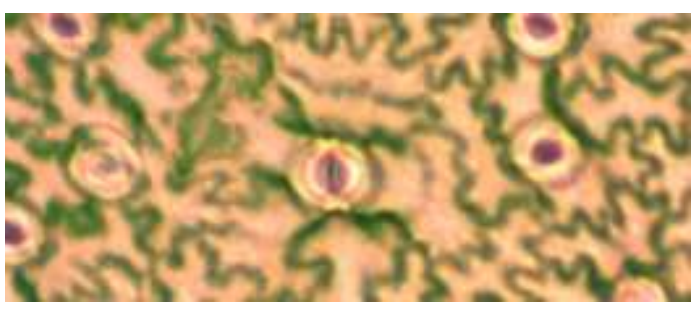

Figure 2. Parts of stomata

The distribution of mahogany leaf stomata at the two locations showed no difference, namely with the hypostomatic type (stomata were only found on the surface of the lower leaves). Haryanti research results [17] showed that monocotyledonous and dicotyledonous plants that grow on land have a lot of stomata on the underside of the leaves except onlang, pineapple, cantel and palm plants found on the upper surface of the leaf. This is reinforced by Campbell [18] which states, in general, the number of stomata is more located on the underside of the leaf which is a mechanism of adaptation of trees to the environment to reduce transpiration

Jalan Khatib Sulaiman, dan Jalan Rasuna Said). Jurnal Buana, 2 (2) ISSN: 2615-2630.

[5] Kovacs, M. 1992. Biological Indicators in Environmental Protection Market Cross House. England.

[6] Karliansyah, N.S.W. 1999. Klorofil Daun Angsana dan Mahoni sebagai Bioindikator Pencemaran Udara. $J$ Lingk. Pemb, 19 (4): 290-305.

[7] Papuangan, N., Nurhasanah, dan M. Djurumudi. 2014. Jumlah dan Distribusi Stomata pada Tanaman Penghijauan di Kota Ternate. Jurnal Bioeducasi, 3 (1) ISSN: 2301-4678.

[8] Rachmawati. 2006. Uji Pencemaran Udara oleh Partikulat Debu di Sekitar Terminal Lebak Bulus Berdasarkan Bioindikator Stomata pada Tanaman Glodokan (Polyalthia longifolia). Skripsi. Jurusan Biologi Fakultas Sains dan Teknologi Universitas Islam Negeri Syarif Hidayatullah. Jakarta.

[9] Nazaruddin. 1994. Penghijauan Kota. Jakarta: Swadaya.

[10] Dahlan, E.N. 2004. Membangun Kota Kebun (Garden City) Bernuansa Hutan Kota. Bogor: IPB Press. 
[11] Raharjo, H. P., S. Haryanti, dan R. Budihastuti. 2015. Pengaruh Tingkat Kepadatan Lalu Lintas dan Waktu Pengamatan yang Berbeda Terhadap Ukuran dan Jumlah Stomata Daun Glodokan (Polyalthia longifolia .Sonn). Jurnal Biologi, 4 (1): 73-84.

[12] Lestari, E.G. 2006. Hubungan antara Stomata dengan Ketahanan Kekeringan pada Somaklon Padi Gajahmungkur, Towuti, dan IR 64. Biodiversitas, 7 (1): 44-48.

[13] Setjo, S., dkk. 2004. Anatomi Tumbuhan. Malang: JICA UM.

[14] Mutaqin, A. Z., R. Budiono, T. Setiawati, M. Nurzaman, dan R. S. Fauzia. 2016. Studi Anatomi Daun Mangga (Mangifera indica) Berdasarkan Perbedaan Lingkungan, Jurnal Biodjati, 1 (1) ISSN: 2541-4208.

[15] Vauzia, Syamsuardi, M. Chairul, and A. Syarif. 2016. Stomata characteristics and chlorophyll content in two plant species regenerating with sprout and seeds after at Peat Swamp Forest in Batang Alin-Indonesia. Journal of Chemical and Pharmaceutical Research. 8 (1): 356-361.Budiyono, A. 2001. Pencemaran Udara: Dampak Pencemaran Udara pada Lingkungan. Berita Dkgantaia, 2 (1): 22-27.

[16] Prawiranata, S. H., dan P. Tjondronegoro. 1995. Fisiologi Tumbuhan Jilid 2. Bogor: IPB.

[17] Haryanti, S. 2010. Jumlah dan Distribusi Stomata pada Daun Beberapa Spesies Tanaman Dikotil dan Monokotil. Buletin Anatomi dan Fisiologi, 18 (2).

[18] Campbell, N.A. 2003. Biologi Edisi Kelima Jilid II. Jakarta: Erlangga 